\title{
Salt intake and blood pressure in Iranian children and adolescents: a population-based study
}

\author{
Mohammad Hassan Emamian ${ }^{1}$, Hossein Ebrahimi ${ }^{2}$, Hassan Hashemi ${ }^{3}$ and Akbar Fotouhi ${ }^{4^{*}}$
}

\begin{abstract}
Background: Previous studies have reported a high prevalence of hypertension in Iranian students, especially in rural areas. The aim of this study was to investigate the daily intake of salt in students and its association with high blood pressure.

Methods: A random sub-sample was selected from the participants of the second phase of Shahroud schoolchildren eye cohort study and then a random urine sample was tested for sodium, potassium and creatinine. Urine electrolyte esexcretion and daily salt intake were calculated by Tanaka et al's formula.

Results: Among 1455 participants (including 230 participants from rural area and 472 girls), the mean age was $12.9 \pm 1.7$ year and the mean daily salt intake was $9.7 \pm 2.6 \mathrm{~g}(95 \% \mathrm{Cl} 9.5-9.8)$. The mean salt consumption in rural areas [10.8 (95\% Cl 10.4-11.2)] was higher than urban areas [9.4 (95\% Cl 9.3-9.6)], in people with hypertension [10.8 (95\% Cl 10.3-11.3)] was more than people with normal blood pressure [9.4 (95\% Cl 9.3-9.6)], and in boys [9.8 (95\% Cl 9.7-10.0)] was more than girls [9.3 (95\% Cl 9.1-9.6)]. Higher age, BMI z-score, male sex and rural life, were associated with increased daily salt intake. Increased salt intake was associated with increased systolic and diastolic blood pressure.

Conclusion: Daily salt intake in Iranian adolescents was about 2 times the recommended amount of the World Health Organization, was higher in rural areas and was associated with blood pressure. Reducing salt intake should be considered as an important intervention, especially in rural areas.
\end{abstract}

Keywords: Children, Hypertension, Iran, Risk factor, Salt intake

\section{Introduction}

Globally $70 \%$ of the causes of death in 2019 were due to non-communicable diseases, which has been increasing over the past years. Ischemic heart disease is responsible for $16 \%$ of deaths and is the leading cause of death. It is estimated that 1.13 billion people worldwide have high blood pressure, and two-thirds of them live in lowand middle-income countries. High blood pressure is a

\footnotetext{
*Correspondence: afotouhi@tums.ac.ir

${ }^{4}$ Department of Epidemiology and Biostatistics, School of Public Health,

Tehran University of Medical Sciences, Tehran, Iran

Full list of author information is available at the end of the article
}

major cause of premature death in the world and reducing its prevalence by $25 \%$ by 2025 compared to 2010 , is a global target, recommended by World Health Organization. However, the prevalence of high blood pressure is increasing, especially in developing countries [3].

High systolic blood pressure (SBP) has the largest impact on the number of deaths in the whole country and all provinces of Iran. Non-optimal control of SBP has reduced life expectancy in Iranian men and women by 3.2 and 4.1 years, respectively [4]. However high blood pressure in Iranian children is not fully investigated and High blood pressure is common even in Iranian children 
and adolescents [5], but there are still not many studies in this field.

We recently have shown a high prevalence of hypertension in Iranian children aged 6-12 years old in a large population-based study [6]. In that study the prevalence of hypertension and prehypertension in rural area were 14.96 and $22.70 \%$ respectively. Surprisingly in that study, the prevalence of prehypertension in rural children was about two times of urban children and the prevalence of hypertension in the rural area was about four times of urban children [6].

Defining the causes of hypertension in children, especially in the rural area was very important in policymaking. Policymakers should rapidly recognize the risk factors and causes of this situation and develop and run appropriate intervention.

One hypothesis for the high prevalence of hypertension in rural children is high intake of sodium. Some researchers had investigated the daily salt intake even in children [7], however there was not sufficient evidence about difference of salt intake by residence place and at best of our knowledge, there was no study about sodium intake in Iranian children.

In a recent national study, daily salt intake in people over 25 in Iran was reported at $9.52 \mathrm{~g} /$ day [8]. This salt consumption which is about twice the standard of the World Health Organization [9], is almost similar to the United Kingdom (9.0) and the United States (10.1) [10], more than Australia (8.7) [11], less than the India (10.98) [12], Latin America (10.49) [13], Japan (13.1) [10] and China (15.1) [10].

By measurements of sodium excretion from urine, we could compare the nutritional habits of urban and rural children. This study aims to investigate daily salt intake in children and adolescents and its associated factors including age, sex, body mass index and residence place. Another aim of this study is to investigate the relationship between blood pressure and salt intake. The results of this study would be very important for policymaking and public health.

\section{Methods}

This study is a part of the 2nd phase of Shahroud schoolchildren Eye Cohort Study (SSCECS). The methodology of SSCECS was reported previously [14]. In brief 5620 schoolchildren aged 6-12 years in Shahroud, northeast Iran, participated in the study in 2015. By considering classrooms as clusters, children selected by random cluster sampling in the urban area and to have larger sample in rural area and also giving health services to these children, all children in the rural area invited to the study. In the 2nd phase of SSCECS, all students who participated in the 1st phase (5620 students) were invited for an eye examination, anthropometry, blood pressure measurements and interviews in 2018. A subsample of these students was randomly selected for checking spot urine $\mathrm{Na}$, $\mathrm{K}$, and $\mathrm{Cr}$ excretion.

Although 24-h urine sample is the best choice for measuring daily salt intake and recent evidences indicate potential risk for misclassification at the individual level by using spot urine samples [15], currently it is approved that a spot urine sample can fairly be used for estimation of salt intake at a population level [16-20]. Previous studies showed that casual urine $\mathrm{Na} / \mathrm{K}$ ratio is a good estimate for 24- $\mathrm{h} \mathrm{NaCl}$ excretion and urinary $\mathrm{Na} / \mathrm{K}$ ratio especially in population level [21-24]. Given the high sample size in this study and feasibility for using spot urine, we assessed spot urine sample instead of $24 \mathrm{~h}$ urine sample.

After a careful explanation about the objectives of the study and obtaining informed consent from children and their parents, a causal mid-stream random urine sample was taken into a disposable urine cup. Urine samples were not collected if female participants were in the first 5 days of menstruation. Samples were transported to laboratory and analyzed on the same day. Urine samples were discarded if urine specific gravity was less than 1.005. Urine samples were analyzed for $\mathrm{Na}, \mathrm{K}$ and $\mathrm{Cr}$ by an automated electrolyte analyzer and Ion Selective Electrode method (i-Smart 30 Pro electrolyte analyzer, Korea).

Among the eight formula for estimating population daily salt intake from a spot urine sample, the Tanaka approach is one of the best and was approved as a correct method even in children and young adolescents $[17,19]$. Recently it also confirmed as a good method for estimating daily salt intake from a spot urine sample in the Iranian population [25].

The daily $\mathrm{Na}$ and $\mathrm{K}$ excretion were calculated by the formulae, proposed by Tanaka et al. [24] as below:

1. Predicted value of $24 \mathrm{~h}$ Creatinine excretion $(\mathrm{PRCr}) \quad(\mathrm{mg} /$ day $)=-2.04 \times$ age $+14.89 \times$ weight $(\mathrm{kg})+16.14 \times$ height $(\mathrm{cm})-2244.45$;

2. Estimated $24 \mathrm{~h}$ urine sodium excretion (mEq/ day $)=21.98 \times \mathrm{XNa}^{0.392}$; where $\left(\mathrm{XNa}=\left(\mathrm{Na}_{\text {spot }} / \mathrm{Cr}_{\mathrm{mg} /}\right.\right.$ L)) $\mathrm{PRCr}$.

3. Estimated $24 \mathrm{~h}$ urine Potassium excretion (mEq/ day $)=7.59 \times \mathrm{XK}^{0.431} ; \quad$ where $\quad\left(\mathrm{XK}=\left(\mathrm{K}_{\mathrm{spot}} / \mathrm{Cr}_{\mathrm{mg} /}\right.\right.$ L) ${ }^{*} \mathrm{PRCr}$.

By considering that $1 \mathrm{~g} \mathrm{Na}=2.54 \mathrm{~g} \mathrm{NaCl}$ and $1 \mathrm{mEq}$ $\mathrm{Na}=1 \mathrm{mmol} \mathrm{Na}$, the daily salt intake was calculated using following formula: $\mathrm{NaCl}(\mathrm{g} / 24 \mathrm{~h})=\mathrm{Na}$ $(\mathrm{mmol} / 24 \mathrm{~h}) * 58.4 / 1000$.

About $90 \%$ of salt intake is excreted into urine and the remaining is lost through sweating and feces [26]. 
Therefore, it was advised to divide the estimated daily $\mathrm{NaCl}$ excretion in the urine by $90 \%$ of the value to estimate correct daily salt intake. However, in this study age group with minimum activity and temperate climate of study location, the urinary sodium excretion can be considered approximately equal to sodium intake [26].

Height of the participants was measured using a wallmounted stature meter with an accuracy of $0.1 \mathrm{~cm}$. Students' weight was measured using a digital scale with an accuracy of $0.1 \mathrm{~kg}$. Similar to our previous work [6], the diagnosis of hypertension was based on measurements of z-scores for children's height, systolic blood pressure and diastolic blood pressure. Prehypertension was defined as $1.28 \leq \mathrm{z}<1.645$ and hypertension was defined as $z$-score $\geq 1.645$, both in systolic or diastolic blood pressure.

The mean, standard deviation and 95\% confidence intervals for urine $\mathrm{Na}, \mathrm{K}, \mathrm{Na} / \mathrm{K}$ ratio and estimated salt intake were reported by children's age, sex, residence place, and hypertension status. Any differences in the above means were assessed by t-test and ANOVA. Scheffe multiple-comparison tests were performed for hypertension groups, where ANOVA tests were significant. The association of daily salt intake and $\mathrm{Na} / \mathrm{K}$ ratio with blood pressure, body mass index, age, sex, and residence place were investigated with multiple linear regression models. The effect of cluster sampling on standard errors and sampling weight in urban and rural areas were considered in calculation of confidence intervals. All analyses were done using statistical package Stata V11.0. $p$ values less than 0.05 were considered as significant.

\section{Results}

All participants in the first phase (5620 individuals) were followed, and finally 5292 students $(94.2 \%)$ participated in the second phase of the study. A urine sample was taken for 1499 individuals. Sodium, potassium, and creatinine tests were performed on 1455 samples, and 44 samples were excluded from the analysis due to low volume or poor quality (low specific gravity) and outlier data (one case). The final analysis was performed on 1,455 students (including 230 participants from rural area and 472 girls). The mean age of participants in this study was 12.9 years with a standard deviation of 1.7 years.

The mean daily salt intake was $9.7 \pm 2.6 \mathrm{~g}$ (95\% CI 9.5-9.8). By adding $10 \%$ to the estimate of sodium loss through sweating and defecation, the mean daily salt intake was $10.6 \pm 2.8$ (95\% CI 10.5-10.8). Table 1 shows more description of daily salt intake as well as daily sodium, potassium, creatinine, and sodium-to-potassium excretion ratio by sex, place of residence, and age groups. As can be seen in this table, the mean salt consumption in rural areas [10.8 (95\% CI 10.4-11.2)] is higher than in urban areas [9.4 (95\% CI 9.3-9.6)], in people with high blood pressure is higher than normal blood pressure [10.8 (95\% CI 10.3-11.3) vs (9.4 (95\% CI 9.3-9.6)], and in boys [9.8 (95\% CI 9.7-10.0)] is more than girls [9.3 (95\% CI 9.1-9.6)]. Salt consumption increased with increasing in age.

Multiple comparison tests in Table 2 show that respect to normal blood pressure group, urine excretion of $\mathrm{Na}$, $\mathrm{Na} / \mathrm{K}$ ratio and $\mathrm{NaCL}$ are higher in hypertension and prehypertension groups, while $\mathrm{K}$ does not differ between blood pressure groups. The mean differences between hypertension and pre-hypertension groups were not significant for all investigated urine electrolytes.

Table 3 shows the association between the independent variables with daily salt consumption, the sodium to potassium ratio in the random urine sample, and the daily sodium to potassium ratio of the estimated daily urine in the multiple linear regression models. Increasing age from 9 to 15 years, increasing BMI z-score, male gender and rural life were all associated with increased daily salt intake.

The association between systolic and diastolic blood pressure and salt consumption is shown in Fig. 1. Compared to diastolic blood pressure, increasing salt consumption is more strongly associated with increased systolic blood pressure. Table 4 also shows the association between systolic and diastolic blood pressure and daily salt intake in two multiple linear regression models, adjusted with age, gender, residence place and BMI-z score. Systolic and diastolic blood pressures increased by $1 \mathrm{mmHg}$ for every $0.41 \mathrm{~g}$ and $0.18 \mathrm{~g}$ increase in daily salt consumption respectively. Although increased salt intake increases systolic and diastolic blood pressure, the place of residence has the greatest effect on the blood pressure (Table 4).

The distribution of daily salt intake according to the residence place is shown in Fig. 2 which shows that its distribution is almost normal and the rural students clearly have a shifted to the right distribution and receive more daily salt. Figure 3 shows the distribution of daily salt intake by different blood pressure groups. As expected, students with hypertension and pre-hypertension receive more daily salt.

\section{Discussion}

This study investigated salt consumption in Iranian children for the first time in an area with a high prevalence of hypertension. The results of this study showed that the mean salt consumption in 9-15-year-old Iranian adolescents $(9.7 \mathrm{~g} / \mathrm{d})$ is high and about twice the recommended level by the World Health Organization [9]. Salt consumption was higher in boys and rural areas. Systolic and diastolic blood pressure were also positively associated 
Table 1 The mean, standard deviation and $95 \%$ confidence intervals (in parentheses) of Sodium, Potassium, and daily salt intake by age, sex, residence place and hypertension status, Shahroud, Iran, 2018

\begin{tabular}{|c|c|c|c|c|c|c|c|c|}
\hline \multirow{2}{*}{$\begin{array}{l}\text { Independent } \\
\text { variables }\end{array}$} & \multirow[t]{2}{*}{$\mathrm{n}$} & \multicolumn{3}{|l|}{ Spot urine } & \multicolumn{4}{|c|}{ Calculated in $24 \mathrm{~h}$} \\
\hline & & $\mathrm{Na}(\mathrm{mmol} / \mathrm{L})$ & $\mathrm{K}(\mathrm{mmol} / \mathrm{L})$ & $\mathrm{Cr}(\mathrm{mg} / \mathrm{dl})$ & $\mathrm{Na}(\mathrm{mmol} / \mathrm{L})$ & $\mathrm{K}(\mathrm{mmol} / \mathrm{L})$ & $\mathrm{Na} / \mathrm{K}$ & $\mathrm{NaCl}$ (g/day) \\
\hline \multicolumn{9}{|l|}{ Sex } \\
\hline Male & 983 & $\begin{array}{l}217.6 \pm 67.2 \\
\quad(213.3-221.8)\end{array}$ & $\begin{array}{c}76.8 \pm 32.9 \\
(74.7-78.8)\end{array}$ & $\begin{array}{l}126.1 \pm 58.0 \\
\quad(122.4-129.7)\end{array}$ & $\begin{array}{l}168.1 \pm 44.1 \\
\quad(165.3-170.8)\end{array}$ & $\begin{array}{l}44.2 \pm 11.0 \\
\quad(43.6-44.9)\end{array}$ & $\begin{array}{l}3.9 \pm 0.9 \\
(3.8-3.9)\end{array}$ & $\begin{array}{l}9.8 \pm 2.6 \\
(9.7-10.0)\end{array}$ \\
\hline Female & 472 & $\begin{array}{l}218.4 \pm 77.2 \\
\quad(211.4-225.3)\end{array}$ & $\begin{array}{c}76.7 \pm 32.4 \\
(73.8-79.6)\end{array}$ & $\begin{array}{l}136.2 \pm 68.3 \\
\quad(130.0-142.4)\end{array}$ & $\begin{array}{l}159.5 \pm 44.1 \\
\quad(155.5-163.5)\end{array}$ & $\begin{array}{l}41.9 \pm 9.8 \\
\quad(41.0-42.8)\end{array}$ & $\begin{array}{l}3.9 \pm 0.8 \\
(3.8-3.9)\end{array}$ & $9.3 \pm 2.6(9.1-9.6)$ \\
\hline$p$ value & & 0.838 & 0.975 & 0.003 & $<0.001$ & $<0.001$ & 0.780 & $<0.001$ \\
\hline \multicolumn{9}{|l|}{ Age (years) } \\
\hline 9 & 47 & $\begin{array}{l}207.5 \pm 68.3 \\
\quad(188.0-227.1)\end{array}$ & $\begin{array}{c}74.9 \pm 33.0 \\
(65.5-84.3)\end{array}$ & $\begin{array}{c}113.0 \pm 49.4 \\
(98.9-127.2)\end{array}$ & $\begin{array}{l}132.1 \pm 40.2 \\
\quad(120.6-143.6)\end{array}$ & $\begin{array}{l}34.2 \pm 10.6 \\
(31.1-37.2)\end{array}$ & $\begin{array}{l}4.0 \pm 0.9 \\
(3.7-4.2)\end{array}$ & $7.7 \pm 2.3(7.1-8.4)$ \\
\hline 10 & 228 & $\begin{array}{l}207.0 \pm 70.0 \\
\quad(197.9-216.1)\end{array}$ & $\begin{array}{c}74.9 \pm 31.4 \\
(70.9-79.0)\end{array}$ & $\begin{array}{l}106.9 \pm 50.2 \\
\quad(100.4-113.4)\end{array}$ & $\begin{array}{l}144.8 \pm 39.3 \\
\quad(139.7-149.9)\end{array}$ & $\begin{array}{c}38.5 \pm 10.5 \\
(37.1-39.8)\end{array}$ & $\begin{array}{l}3.9 \pm 0.8 \\
(3.7-4.0)\end{array}$ & $8.5 \pm 2.3(8.2-8.8)$ \\
\hline 11 & 293 & $\begin{array}{l}210.3 \pm 72.8 \\
\quad(201.9-218.7)\end{array}$ & $\begin{array}{l}83.1 \pm 34.7 \\
(79.1-87.0)\end{array}$ & $\begin{array}{l}124.6 \pm 62.4 \\
\quad(117.5-131.8)\end{array}$ & $\begin{array}{l}154.1 \pm 44.7 \\
\quad(148.9-159.2)\end{array}$ & $\begin{array}{l}42.1 \pm 10.0 \\
\quad(41.0-43.3)\end{array}$ & $\begin{array}{l}3.7 \pm 0.8 \\
(3.6-3.8)\end{array}$ & $9.0 \pm 2.6(8.7-9.3)$ \\
\hline 12 & 298 & $\begin{array}{l}222.4 \pm 69.5 \\
(214.5-230.3)\end{array}$ & $\begin{array}{l}77.6 \pm 30.7 \\
\quad(74.1-81.1)\end{array}$ & $\begin{array}{l}123.4 \pm 52.3 \\
\quad(117.5-129.4)\end{array}$ & $\begin{array}{c}171.9 \pm 41.3 \\
\quad(167.2-176.6)\end{array}$ & $\begin{array}{l}45.3 \pm 9.1 \\
\quad(44.3-46.3)\end{array}$ & $\begin{array}{l}3.8 \pm 0.8 \\
(3.8-3.9)\end{array}$ & $\begin{array}{c}10.0 \pm 2.4 \\
(9.8-10.3)\end{array}$ \\
\hline 13 & 215 & $\begin{array}{l}226.1 \pm 66.7 \\
(217.2-235.0)\end{array}$ & $\begin{array}{l}76.0 \pm 30.7 \\
\quad(71.9-80.1)\end{array}$ & $\begin{array}{l}135.9 \pm 55.2 \\
\quad(128.5-143.3)\end{array}$ & $\begin{array}{l}175.3 \pm 37.8 \\
\quad(170.3-180.4)\end{array}$ & $\begin{array}{l}45.8 \pm 9.4 \\
\quad(44.5-47.1)\end{array}$ & $\begin{array}{l}3.9 \pm 0.8 \\
(3.8-4.0)\end{array}$ & $\begin{array}{l}10.2 \pm 2.2 \\
\quad(10.0-10.5)\end{array}$ \\
\hline 14 & 239 & $\begin{array}{l}220.2 \pm 71.8 \\
(211.1-229.3)\end{array}$ & $\begin{array}{c}70.8 \pm 31.7 \\
(66.8-74.9)\end{array}$ & $\begin{array}{l}144.7 \pm 68.4 \\
\quad(136.1-153.4)\end{array}$ & $\begin{array}{c}179.3 \pm 44.4 \\
\quad(173.7-185.0)\end{array}$ & $\begin{array}{l}45.8 \pm 10.5 \\
\quad(44.4-47.1)\end{array}$ & $\begin{array}{l}4.0 \pm 0.9 \\
(3.9-4.1)\end{array}$ & $\begin{array}{l}10.5 \pm 2.6 \\
\quad(10.1-10.8)\end{array}$ \\
\hline 15 & 135 & $\begin{array}{l}228.4 \pm 70.5 \\
(216.5-240.3)\end{array}$ & $\begin{array}{l}76.4 \pm 37.6 \\
(70.1-82.8)\end{array}$ & $\begin{array}{l}158.6 \pm 77.8 \\
\quad(145.5-171.7)\end{array}$ & $\begin{array}{l}180.2 \pm 44.1 \\
\quad(172.7-187.6)\end{array}$ & $\begin{array}{l}46.3 \pm 12.4 \\
\quad(44.2-48.4)\end{array}$ & $\begin{array}{l}4.0 \pm 1.0 \\
(3.8-4.2)\end{array}$ & $\begin{array}{l}10.5 \pm 2.6 \\
\quad(10.1-11.0)\end{array}$ \\
\hline$p$ value & & 0.009 & 0.003 & $<0.001$ & $<0.001$ & $<0.001$ & 0.001 & $<0.001$ \\
\hline \multicolumn{9}{|c|}{ Residence place } \\
\hline Urban & 1225 & $\begin{array}{l}209.9 \pm 64.6 \\
\quad(206.3-213.5)\end{array}$ & $\begin{array}{l}77.5 \pm 33.2 \\
\quad(75.6-79.4)\end{array}$ & $\begin{array}{l}131.6 \pm 62.0 \\
\quad(128.1-135.1)\end{array}$ & $\begin{array}{l}161.6 \pm 42.1 \\
\quad(159.2-163.9)\end{array}$ & $\begin{array}{l}43.3 \pm 10.7 \\
\quad(42.7-43.9)\end{array}$ & $\begin{array}{l}3.8 \pm 0.8 \\
(3.8-3.9)\end{array}$ & $9.4 \pm 2.5(9.3-9.6)$ \\
\hline Rural & 230 & $\begin{array}{l}260.1 \pm 84.8 \\
\quad(249.0-271.1)\end{array}$ & $\begin{array}{c}72.7 \pm 29.9 \\
(68.8-76.6)\end{array}$ & $\begin{array}{l}117.4 \pm 58.9 \\
\quad(109.7-125.0)\end{array}$ & $\begin{array}{l}185.1 \pm 49.8 \\
\quad(178.6-191.6)\end{array}$ & $\begin{array}{l}44.7 \pm 10.3 \\
\quad(43.3-46.0)\end{array}$ & $\begin{array}{l}4.2 \pm 0.9 \\
\quad(4.1-4.3)\end{array}$ & $\begin{array}{c}10.8 \pm 2.9 \\
(10.4-11.2)\end{array}$ \\
\hline$p$ value & & $<0.001$ & 0.041 & 0.001 & $<0.001$ & 0.061 & $<0.001$ & $<0.001$ \\
\hline \multicolumn{9}{|l|}{ Blood pressure } \\
\hline Normal & 1182 & $\begin{array}{l}209.1 \pm 65.3 \\
\quad(205.4-212.9)\end{array}$ & $\begin{array}{c}76.8 \pm 32.6 \\
(74.9-78.7)\end{array}$ & $\begin{array}{l}130.6 \pm 61.1 \\
\quad(127.1-134.1)\end{array}$ & $\begin{array}{l}161.4 \pm 42.0 \\
\quad(159.0-163.8)\end{array}$ & $\begin{array}{l}43.1 \pm 10.4 \\
\quad(42.5-43.7)\end{array}$ & $\begin{array}{l}3.8 \pm 0.8 \\
(3.8-3.9)\end{array}$ & $9.4 \pm 2.5(9.3-9.6)$ \\
\hline Pre HTN & 144 & $\begin{array}{l}263.5 \pm 77.4 \\
(250.8-276.1)\end{array}$ & $\begin{array}{c}76.5 \pm 31.5 \\
(71.4-81.7)\end{array}$ & $\begin{array}{l}122.4 \pm 55.5 \\
\quad(113.4-131.5)\end{array}$ & $\begin{array}{l}180.1 \pm 47.2 \\
\quad(172.4-187.9)\end{array}$ & $\begin{array}{c}43.9 \pm 11.3 \\
(42.0-45.7)\end{array}$ & $\begin{array}{l}4.2 \pm 1.0 \\
\quad(4.1-4.4)\end{array}$ & $\begin{array}{l}10.5 \pm 2.8 \\
(10.1-11.0)\end{array}$ \\
\hline HTN & 125 & $\begin{array}{l}247.2 \pm 82.1 \\
\quad(232.8-261.6)\end{array}$ & $\begin{array}{c}76.6 \pm 35.1 \\
(70.5-82.7)\end{array}$ & $\begin{array}{l}125.7 \pm 73.3 \\
\quad(112.9-138.5)\end{array}$ & $\begin{array}{l}185.0 \pm 52.1 \\
\quad(175.8-194.1)\end{array}$ & $\begin{array}{l}46.6 \pm 11.9 \\
(44.5-48.7)\end{array}$ & $\begin{array}{l}4.1 \pm 0.9 \\
(3.9-4.2)\end{array}$ & $\begin{array}{l}10.8 \pm 3.0 \\
(10.3-11.3)\end{array}$ \\
\hline$p$ value & & $<0.001$ & 0.995 & 0.250 & $<0.001$ & 0.002 & $<0.001$ & $<0.001$ \\
\hline $\begin{array}{l}\text { Total partici- } \\
\text { pants }\end{array}$ & 1455 & $\begin{array}{l}217.8 \pm 70.6 \\
\quad(214.2-221.5)\end{array}$ & $\begin{array}{c}76.7 \pm 32.7 \\
(75.1-78.4)\end{array}$ & $\begin{array}{l}129.3 \pm 61.7 \\
(126.2-132.5)\end{array}$ & $\begin{array}{l}165.3 \pm 44.2 \\
(163.0-167.6)\end{array}$ & $\begin{array}{l}43.5 \pm 10.6 \\
\quad(42.9-44.0)\end{array}$ & $\begin{array}{l}3.9 \pm 0.9 \\
(3.8-3.9)\end{array}$ & $9.7 \pm 2.6(9.5-9.8)$ \\
\hline
\end{tabular}

$\mathrm{Na}$, Sodium; K, Potassium; Cr, Creatinine; $\mathrm{Na} / \mathrm{K}$, Sodium to Potassium ratio; HTN, Hypertension

with salt intake. Although higher salt intake in rural areas partly justifies the increase in the prevalence of hypertension in rural adolescents, there are other factors that need further study.

Rezaei et al. [8] studied salt consumption in people over the age of 25 in different provinces of Iran and estimated it at $9.52 \mathrm{~g}$ per day [8]. The results of current study are very similar to the results of his national study and show that family eating habits determine the salt consumption of all family members $[27,28]$ and Iranian children have also high salt consumption. It should also be noted that in Rezaei et al. study [8], 10\% was added to the value estimated by the Tanaka method, and if this happen in current study, the mean daily salt intake in adolescents $(10.6 \mathrm{~g} / \mathrm{d})$ will be about $1 \mathrm{~g}$ higher than the mean national salt intake for individuals older than 25 years old. The estimation of Rezaei et al. for Semnan province, in which this study was conducted, is slightly higher than the estimate for whole country. Therefore, it can be said that two studies have had similar results. 
Table 2 The Scheffe multiple-comparison tests for mean differences of urine parameters by hypertension groups

\begin{tabular}{|c|c|c|c|c|c|}
\hline \multirow[t]{2}{*}{ Urine parameters } & \multirow[t]{2}{*}{ Hypertension groups } & \multicolumn{2}{|c|}{ Normal blood pressure } & \multicolumn{2}{|l|}{ Pre-hypertension } \\
\hline & & Mean difference & $p$ value & Mean difference & $p$ value \\
\hline \multirow[t]{2}{*}{ Spot urine $\mathrm{Na}(\mathrm{mmol} / \mathrm{L})$} & Pre-hypertension & 54.33 & $<0.001$ & & \\
\hline & Hypertension & 38.03 & $<0.001$ & -16.30 & 0.148 \\
\hline \multirow[t]{2}{*}{ Calculated $24 \mathrm{~h} \mathrm{Na}(\mathrm{mmol} / \mathrm{L})$} & Pre-hypertension & 18.76 & $<0.001$ & & \\
\hline & Hypertension & 23.58 & $<0.001$ & 4.83 & 0.663 \\
\hline \multirow[t]{2}{*}{ Calculated 24 h K (mmol/L) } & Pre-hypertension & 0.76 & 0.716 & & \\
\hline & Hypertension & 3.51 & 0.002 & 2.75 & 0.104 \\
\hline \multirow[t]{2}{*}{ Calculated $24 \mathrm{~h} \mathrm{Na} / \mathrm{K}$} & Pre-hypertension & 0.40 & $<0.001$ & & \\
\hline & Hypertension & 0.24 & $<0.001$ & -0.16 & 0.600 \\
\hline \multirow[t]{2}{*}{ Calculated 24 h NaCl (g/day) } & Pre-hypertension & 1.10 & $<0.001$ & & \\
\hline & Hypertension & 1.38 & $<0.001$ & 0.28 & 0.663 \\
\hline
\end{tabular}

Table 3 The association of independent variables with daily salt intake and $\mathrm{Na} / \mathrm{K}$ ratio in multiple linear regression models, Shahroud, Iran, 2018

\begin{tabular}{|c|c|c|c|c|c|c|}
\hline \multirow[t]{2}{*}{ Independent Variables } & \multicolumn{2}{|c|}{ Estimated daily salt intake } & \multicolumn{2}{|l|}{ Spot urine $\mathrm{Na} / \mathrm{K}$ ratio } & \multicolumn{2}{|c|}{ Estimated daily $\mathrm{Na} / \mathrm{K}$ ratio } \\
\hline & Coefficient $(95 \% \mathrm{Cl})$ & $p$ value & Coefficient $(95 \% \mathrm{Cl})$ & $p$ value & Coefficient $(95 \% \mathrm{Cl})$ & $p$ value \\
\hline Age (years) & $0.49(0.40,0.57)$ & $<0.001$ & $0.13(0.06,0.20)$ & $<0.001$ & $0.04(0.01,0.07)$ & 0.009 \\
\hline BMI z-score & $0.60(0.51,0.69)$ & $<0.001$ & $0.05(-0.02,0.12)$ & 0.138 & $-0.004(-0.03,0.03)$ & 0.181 \\
\hline Sex (male/female) & $0.58(0.28,0.89)$ & $<0.001$ & $0.17(-0.04,0.39)$ & 0.108 & $0.06(-0.06,0.16)$ & 0.608 \\
\hline Residence place (rural/urban) & $1.42(0.96,1.89)$ & $<0.001$ & $0.94(0.63,1.25)$ & $<0.001$ & $0.39(0.201,0.447)$ & $<0.001$ \\
\hline
\end{tabular}

$\mathrm{Na}$, Sodium; $\mathrm{K}$, Potassium; $\mathrm{Cl}$, Confidence intervals

To the best of our knowledge, another study in Iran did not examine salt intake in adolescents. In children aged 3-10 years in Isfahan, however, a study conducted in 2011-2012 on 241 children [29] showed that young Iranian children consumed large amounts of sodium. Also, the mean urinary sodium in Isfahan was 177.2 (somewhat similar to the results of the present study) and did not differ in sex and place of residence. The main sources of salt in that study were bread, cheese and snacks [29].

Other local studies have been conducted in Iran on the adult population and have had almost the same results as the present study. For example, a study among 20-74-year-olds people in Yazd estimated daily salt intake at $9.13 \mathrm{~g}$ [30]. In Isfahan, the mean salt consumption in people over 18 years of age was 9.5, 9.7, 9.6 and 10.2 g per day in 1998, 2001, 2007 and 2013, respectively [31] and it has been increasing from 2010 to 2014 [32]. Consumption of salt in Tehran in people over 19 years of age was $9.5 \mathrm{~g}$ per day [33]. The differences in the estimates of the above studies can be due to the type of method of measuring urinary sodium, the method of preparing the urine samples and the year of the study.

The results of the above studies show that prevention strategies for high salt consumption in Iran, which is said to have started in 2009 [34] with comprehensive policy at three levels of public information, food factories, and legislation [35] have not been very effective and needs to be seriously reconsidered.

Different levels of daily salt intake have been reported in different studies around the world. For example, it was $5.9 \mathrm{~g} / \mathrm{d}$ in children $6-16$ years old in an area in Switzerland [36], $5.7 \mathrm{~g} / \mathrm{d}$ in Japanese children aged 9-11 years old [37], $7.2 \mathrm{~g} / \mathrm{d}$ in Japanese children aged 6-12 years old [28], $6.5 \mathrm{~g} / \mathrm{d}$ in Portuguese children aged $8-9$ years old [38], 7.8 g/d in 7-11 years old Spanish children [7], 3.8, 4.7 and $7.6 \mathrm{~g}$ in children aged 5-6, 8-9 and 13-17 years old lived in south London respectively [39] and 7.4 and 6.7 in Italian boys and girls aged 6-18 years old [40]. These results show that salt consumption in Iranian adolescents is much higher than in other countries.

In the present study, the mean salt consumption in boys was higher than girls. This has been the case in other studies, such as in Portugal [38] or Italy [40] and even in adulthood [41]. It is believed that this difference reflects the different energy needs of boys and girls, so higher boys' need for energy leads to more food consumption and more salt consumption in them $[38,40]$. 


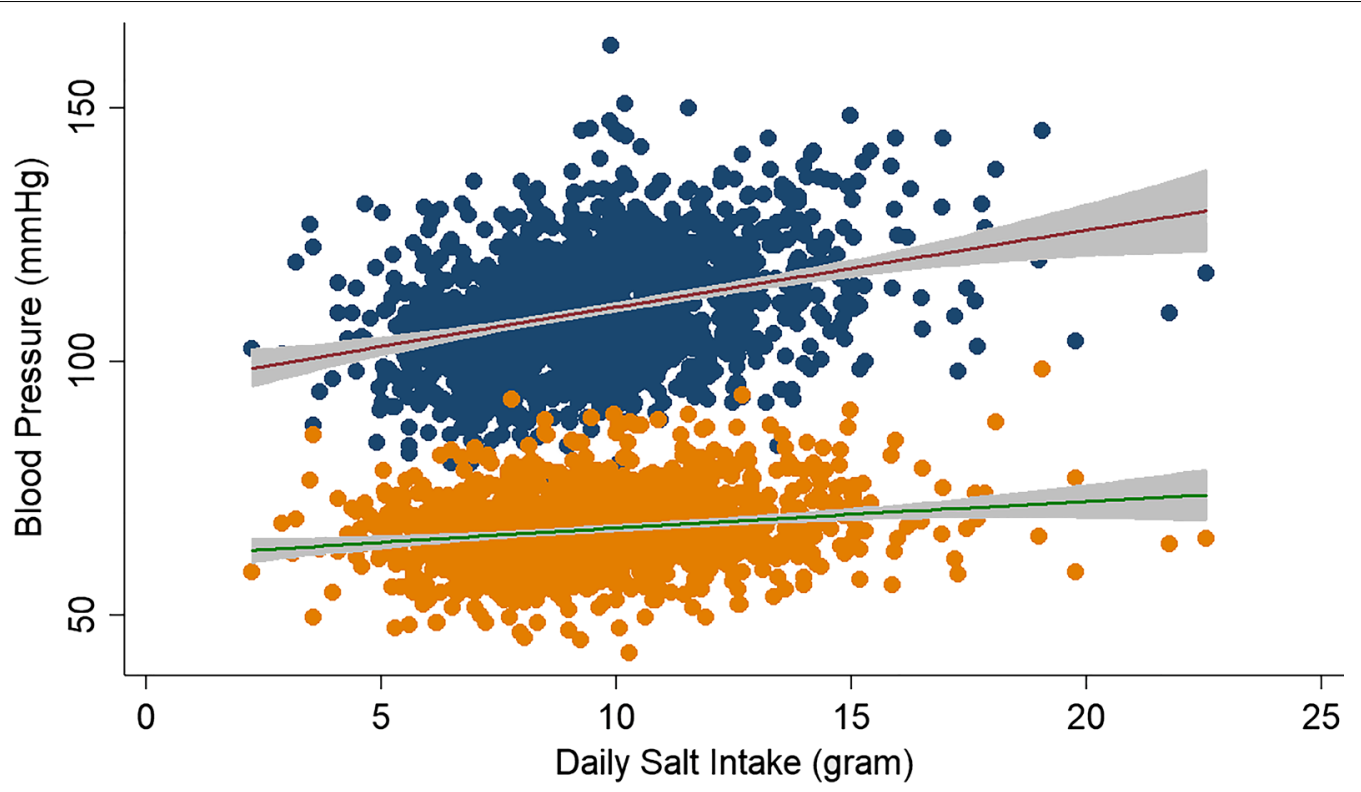

- Systolic Blood Pressure

$95 \%$ Confidence Intervals

- Diastolic Blood Pressure

Fig. 1 The correlation of systolic blood pressure and daily salt intake in 9-15 years old students by residence place, Shahroud, Iran, 2018

Table 4 The association of daily salt intake and other independent variables with systolic and diastolic blood pressure in multiple linear regression models, Shahroud, Iran, 2018

\begin{tabular}{|c|c|c|c|c|}
\hline \multirow[t]{2}{*}{ Independent variables } & \multicolumn{2}{|c|}{ Systolic blood pressure } & \multicolumn{2}{|c|}{ Diastolic blood pressure } \\
\hline & Coefficient $(95 \% \mathrm{Cl})$ & $p$ value & Coefficient $(95 \% \mathrm{Cl})$ & $p$ value \\
\hline Salt intake (g/day) & $0.41(0.17,0.65)$ & 0.001 & $0.18(0.01,0.35)$ & 0.041 \\
\hline Age (years) & $2.01(1.58,2.44)$ & $<0.001$ & $0.77(0.50,1.05)$ & $<0.001$ \\
\hline BMI z-score & $2.79(2.39,3.19)$ & $<0.001$ & $1.02(0.72,1.31)$ & $<0.001$ \\
\hline Sex (male/female) & $1.30(0.07,2.53)$ & 0.038 & $-1.07(-1.92,-0.22)$ & 0.014 \\
\hline Residence place (rural/urban) & $8.20(5.51,10.90)$ & $<0.001$ & $2.81(1.49,4.13)$ & $<0.001$ \\
\hline
\end{tabular}

According to the study results, the mean salt intake increased with increasing in age, BMI z-score and was higher in boys and rural area. In Portuguese children [38], salt intake was higher in boys and obese or overweight people and was similarly associated with systolic blood pressure but not with diastolic blood pressure. In 18-69-year-olds people in Shandong, China; the mean daily urinary sodium excretion was $237.6 \mathrm{mmol}$ and the daily salt intake was $13.9 \mathrm{~g}$, and the mean salt intake was higher in rural men and women [41]. In the same area, daily salt intake was higher in obese and overweight people than in normal weight, and sodium excretion was higher in people with hypertension and was associated with systolic blood pressure [42]. However, in a study by Kelishadi et al. in the age group of 3-10 years, there was no association between sodium intake and urinary excretion of sodium, potassium with systolic and diastolic blood pressure, which could be due to the age group of this study and low sample size [29]. Some studies have linked the association between blood pressure and salt intake to body weight and waist circumference [43]. While in this study, even in the presence of BMI-z score, blood pressure was associated with salt intake. The differences in age group and the prevalence of high blood pressure in these studies could be the reason for different results. In general, studies have shown that reducing 


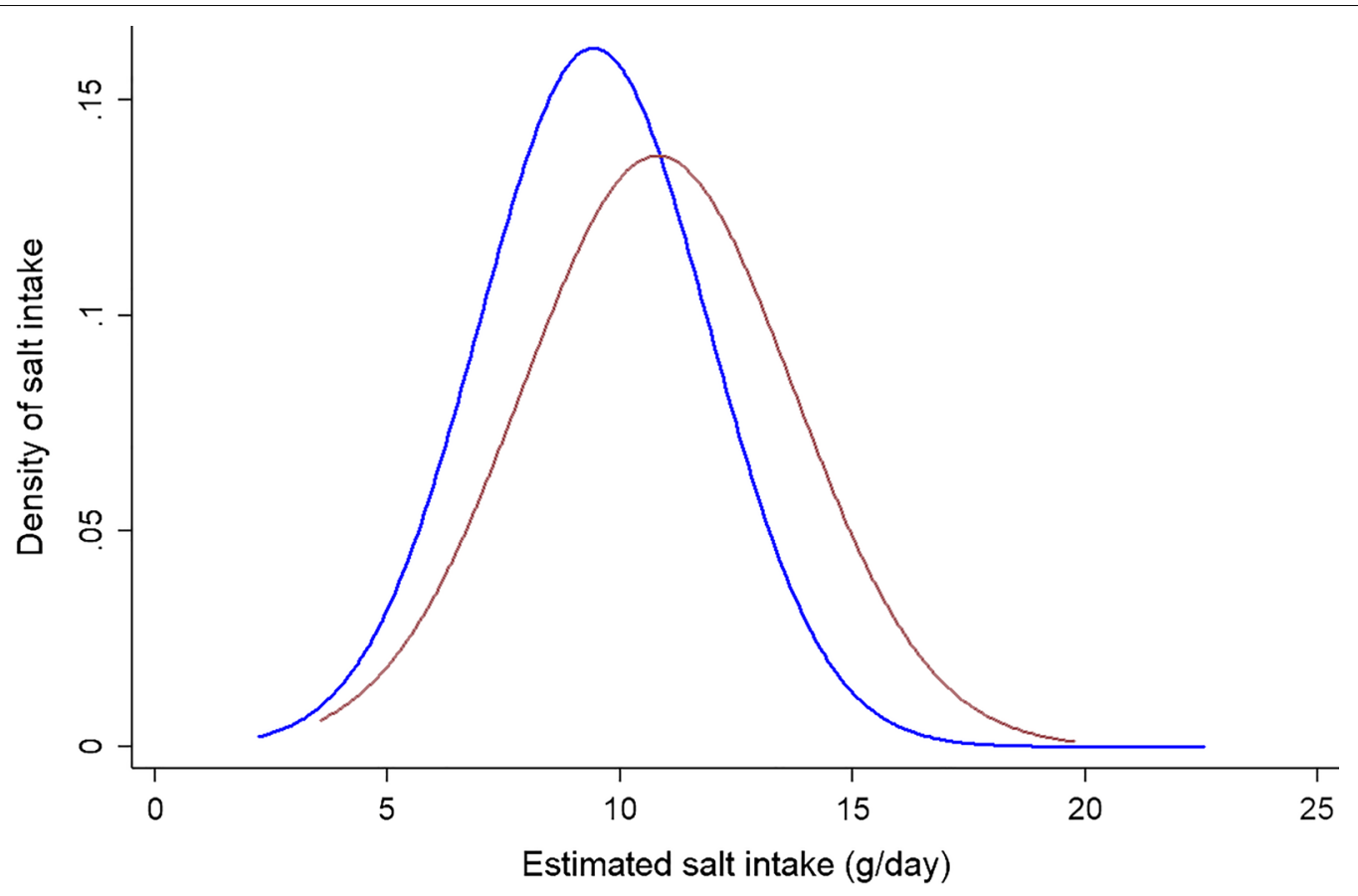

Urban

Rural

Fig. 2 The distribution of daily salt intake in 9-15 years old students by residence place, Shahroud, Iran, 2018

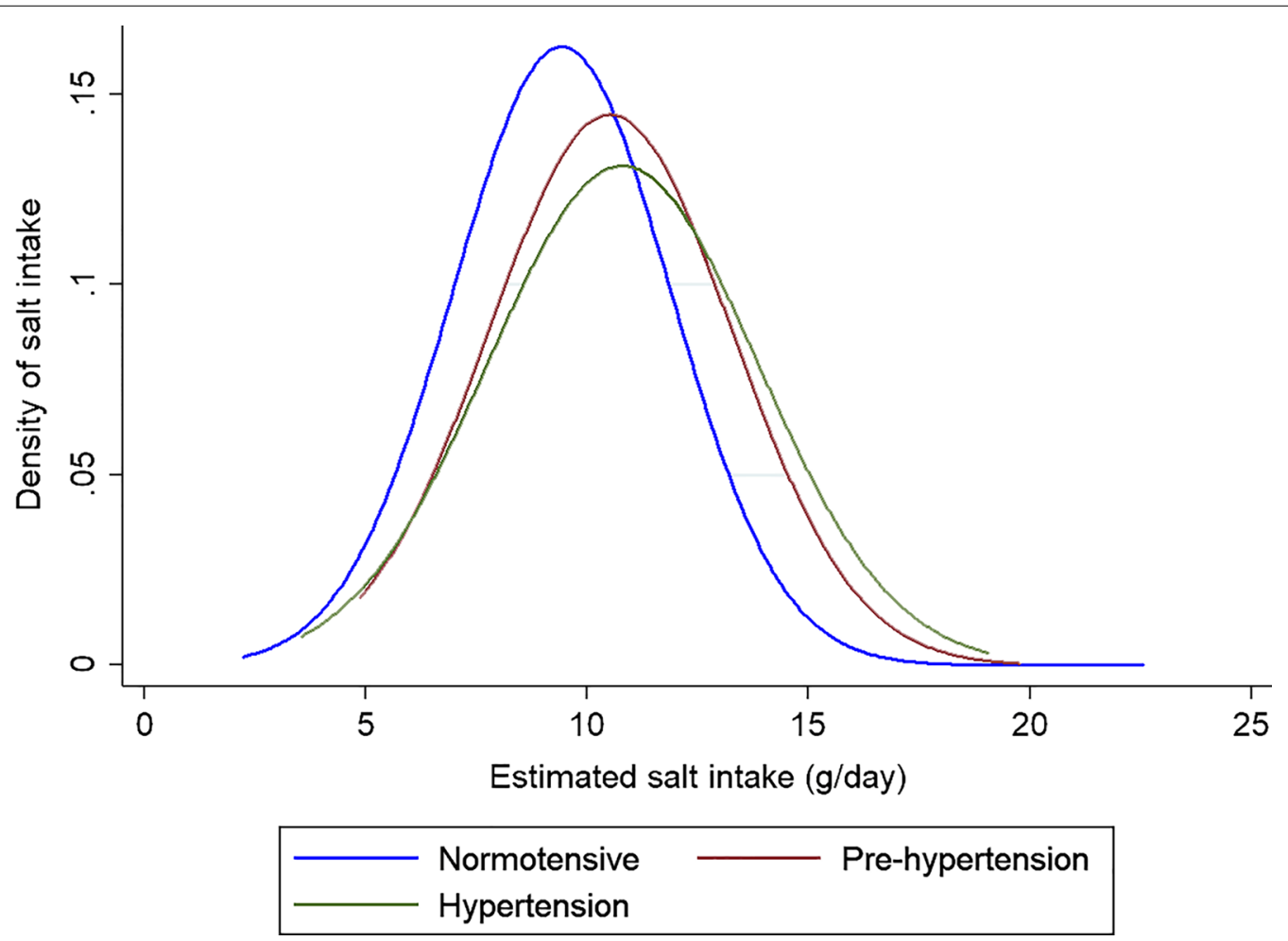

Fig. 3 The distribution of daily salt intake in 9-15 years old students by hypertension groups, Shahroud, Iran, 2018 
salt intake not only lowers blood pressure but also has beneficial effects on vascular function and viscoelastic properties of large arteries [44]. It should be noted that researchers have recently concluded that in examining the association between salt intake and blood pressure, 24-h urinary sodium is more appropriate than the estimated sodium from spot urine [45].

In this study, daily salt consumption in rural areas $(10.8 \mathrm{~g} / \mathrm{d})$ was higher than in urban areas $(9.4 \mathrm{~g} / \mathrm{d})$. This situation is similar to most other studies $[40,46]$. However, daily salt intake in urban areas is also high, and this difference in salt consumption justifies part of the higher prevalence of hypertension and pre-hypertension in rural area of Shahroud [6], and probably other nutritional differences in urban and rural areas are the main reason for the difference of blood pressure distribution in urban and rural areas in Shahroud. The results of a study on 12-19-year-olds adolescents in Shiraz, Iran also showed that western nutrition habits including high consumption of soft drinks, sweets and desserts, salt, mayonnaise, tea and coffee, salty snacks, high-fat dairy, French fries, and red or processed meats, are associated with increased blood pressure [47]. Therefore, in addition to reducing salt consumption, other nutritional interventions [48] are also necessary to reduce blood pressure in this area. Higher salt consumption in rural areas may be due to higher bread consumption, so interventions that reduce amount of bread salt and also bread consumption could lead to a decrease in systolic blood pressure in the short term [49].

The daily potassium excretion in this study was $43.5 \mathrm{mmol}$, which was higher in boys, older students and with no difference in urban and rural areas. This is higher than in countries such as Indonesia [50]-with a daily potassium excretion of 16.4 in children aged 9-12-and China [51] - with a daily excretion of 25.2 in children aged 6-16 years. But it is almost at the level of Italian children aged 6- to 18-year-old [40]. Insufficient potassium intake has been observed in other young populations around the world, for example in the young American population groups [52], among English children aged 7-10 years [53] and among French children [54]. Low Potassium intake in children and adolescents may be due to early dietary experience during infancy [55].

Although in this study, the mean urinary potassium of students with hypertension was higher than that of the normotensive and prehypertensive groups, in the multiple linear regression model and in the presence of other variables such as age, sex and BMI z-score, this association was not significant. This result was similar to other studies in Italy [40] and Uruguay [56]. However, the results of other studies in adults [57-59] show an inverse association between urinary excretion of potassium and blood pressure. Therefore, it is difficult to evaluate the possible effect of adequate consumption of this electrolyte on blood pressure in the study population of this study, where the prevalence of hypertension is high, and further studies are needed.

High sample size, accurate sampling in urban and rural areas and standard laboratory tests are the main strengths of this study, which was performed for the first time in the adolescent age group in Iran. However, the use of a random urine sample, diagnosis of hypertension based on measurement of blood pressure in one occasion, and not examining the, diet, physical activity and sleep of the participants may be considered as limitations of this study.

\section{Conclusions}

The daily salt intake in Iranian adolescents is about twice the level recommended by the World Health Organization. This amount is higher in rural areas and people with high blood pressure, and therefore one way to reduce high blood pressure in rural areas is serious educational and nutritional interventions to reduce salt consumption. This is an important message to policymakers. However, investigating other causes of high prevalence of hypertension in Shahroud as well as continuous monitoring of blood pressure and salt intake is recommended.

\section{Abbreviations}

DBP: Diastolic blood pressure; BMI: Body mass index; SBP: Systolic blood pressure; Cl: Confidence intervals; Na: Sodium; K: Potassium; Cr: Creatinine; ANOVA: Analysis of variances.

\section{Acknowledgements \\ Not applicable.}

\section{Authors' contributions}

MHE drafted the manuscript and contributed in preparation of the study protocol and conceptualized and conducted all statistical analyses and were the primary authors of the article. $\mathrm{HE}$ and $\mathrm{HH}$ contributed in the conceptualization of the paper and the statistical analyses and critically revised the manuscript. AF conceived and designed the study and contributed in preparation of the study protocol and contributed in the conceptualization of the paper and the statistical analyses and critically revised the manuscript. All authors read and approved the final manuscript.

\section{Funding}

Shahroud school children eye cohort study is supported by Noor Eye Hospital and Shahroud University of Medical Sciences (project number: 960351). Research reported in this publication was supported by small grant committee under award number 973472 from the National Institutes for Medical Research Development (NIMAD), Tehran, Iran.

\section{Availability of data and materials}

The datasets used and/or analyzed during the current study are available from the corresponding author on reasonable request.

\section{Ethics approval and consent to participate}

This study was conducted in accordance with the Helsinki Declaration. All procedures involving participants were approved by the Ethics Committee 
of Shahroud University of Medical Sciences (Reference number: IR.SHMU REC.1396.195). We obtained written informed consent from all participants.

\section{Consent for publication}

Not applicable.

\section{Competing interests}

The authors declare that they have no competing interests.

\section{Author details \\ ${ }^{1}$ Ophthalmic Epidemiology Research Center, Shahroud University of Medical Sciences, Shahroud, Iran. ${ }^{2}$ Randomized Controlled Trial Research Center, Shah- roud University of Medical Sciences, Shahroud, Iran. ${ }^{3}$ Noor Ophthalmology Research Center, Noor Eye Hospital, Tehran, Iran. ${ }^{4}$ Department of Epidemiol- ogy and Biostatistics, School of Public Health, Tehran University of Medical Sciences, Tehran, Iran.}

Received: 30 October 2020 Accepted: 18 January 2021 Published online: 02 February 2021

\section{References}

1. World Health Organization. Hypertension key facts. 5 Jan 2021. https:// www.who.int/news-room/fact-sheets/detail/hypertension.

2. World Health Organization. The top 10 causes of death. 5 Jan 2021. https ://www.who.int/news-room/fact-sheets/detail/the-top-10-causes-ofdeath.

3. Ibrahim MM, Damasceno A. Hypertension in developing countries. Lancet. 2012;380:611-9.

4. Farzadfar F, Danaei G, Namdaritabar H, Rajaratnam JK, Marcus JR, Khosravi A, et al. National and subnational mortality effects of metabolic risk factors and smoking in Iran: a comparative risk assessment. Lancet. 2013;381:S47.

5. Fallah Z, Qorbani M, Motlagh ME, Heshmat R, Ardalan G, Kelishadi R. Prevalence of prehypertension and hypertension in a nationally representative sample of Iranian children and adolescents: the CASPIAN-IV study. Int J Prev Med. 2014;5:57-64.

6. Ebrahimi H, Emamian MH, Hashemi H, Fotouhi A. Prevalence of prehypertension and hypertension and its risk factors in Iranian school children: a population-based study. J Hypertens. 2018;36:1816-24.

7. Aparicio A, Rodríguez-Rodríguez E, Cuadrado-Soto E, Navia B, LópezSobaler AM, Ortega RM. Estimation of salt intake assessed by urinary excretion of sodium over $24 \mathrm{~h}$ in Spanish subjects aged 7-11 years. Eur J Nutr. 2017;56:171-8.

8. Rezaei S, Mahmoudi Z, Sheidaei A, Aryan Z, Mahmoudi N, Gohari K, et al. Salt intake among Iranian population: the first national report on salt intake in Iran. J Hypertens. 2018;36:2380-9.

9. World Health Organization. WHO issues new guidance on dietary salt and potassium. 2013. 11 Aug 2019. https://www.who.int/mediacentre/news/ notes/2013/salt_potassium_20130131/en/.

10. Zhou L, Stamler J, Chan Q, Van Horn L, Daviglus ML, Dyer AR, et al. Salt intake and prevalence of overweight/obesity in Japan, China, the United Kingdom, and the United States: the INTERMAP Study. Am J Clin Nutr. 2019:110:34-40

11. Land MA, Neal BC, Johnson C, Nowson CA, Margerison C, Petersen KS. Salt consumption by Australian adults: a systematic review and metaanalysis. Med j Aust. 2018;208:75-81.

12. Johnson C, Praveen D, Pope A, Raj TS, Pillai RN, Land MA, et al. Mean population salt consumption in India: a systematic review. J Hypertens. 2017;35:3-9.

13. Carrillo-Larco RM, Bernabe-Ortiz A. Sodium and salt consumption in Latin America and the Caribbean: a systematic-review and meta-analysis of population-based studies and surveys. Nutrients. 2020;12:556. https://doi. org/10.3390/nu12020556.

14. Emamian $\mathrm{MH}$, Hashemi H, Khabazkhoob M, Malihi S, Fotouhi A. Cohort profile: Shahroud schoolchildren eye cohort study (SSCECS). Int J Epidemiol. 2019:48:27-27f.

15. Peng Y, Zhang Y, Li K, Liu L, Zhang S, Peng X. A new approach is needed to evaluate 24-hour urinary sodium excretion using spot urines: a validation study in a Chinese child population. J Am Heart Assoc. 2020;9:e014575.

16. Chiolero A. Salt intake monitoring at a population level. J Hum Hypertens. 2020;34:604-5.

17. Dong J, Yan Y, Fan H, Zhao X, Mi J. Accuracy validation of 8 equations to estimate 24 -hour sodium by spot urine in young adolescents. Am J Hypertens. 2018:32:257-64.

18. Huang L, Crino M, Wu JH, Woodward M, Barzi F, Land MA, et al. Mean population salt intake estimated from 24-h urine samples and spot urine samples: a systematic review and meta-analysis. Int J Epidemiol. 2016:45:239-50.

19. Rios-Leyvraz M, Bovet P, Tabin R, Genin B, Russo M, Rossier MF, et al. Urine spot samples can be used to estimate 24-hour urinary sodium excretion in children. J Nutr. 2018;148:1946-53.

20. Meyer HE, Johansson L, Eggen AE, Johansen H, Holvik K. Sodium and potassium intake assessed by spot and 24-h urine in the populationbased Tromsø study 2015-2016. Nutrients. 2019;11:1619.

21. Iwahori T, Miura K, Ueshima H, Chan Q, Dyer AR, Elliott P, et al. Estimating 24-h urinary sodium/potassium ratio from casual ('spot') urinary sodium/ potassium ratio: the INTERSALT study. Int J Epidemiol. 2017:46:1564-72.

22. Brown IJ, Dyer AR, Chan Q, Cogswell ME, Ueshima H, Stamler J, et al. Estimating 24-hour urinary sodium excretion from casual urinary sodium concentrations in western populations the INTERSALT study. Am J Epidemiol. 2013;177:1180-92.

23. Bruce NG, Cook DG, Shaper AG, Ratcliffe JG. Casual urine concentrations of sodium, potassium, and creatine in population studies of blood pressure. J Hum Hypertens. 1990;4:597-602.

24. Tanaka T, Okamura T, Miura K, Kadowaki T, Ueshima H, Nakagawa H, et al. A simple method to estimate populational 24-h urinary sodium and potassium excretion using a casual urine specimen. J Hum Hypertens. 2002;16:97.

25. Mohammadifard N, Marateb H, Mansourian M, Khosravi A, Abdollahi Z, et al. Can methods based on spot urine samples be used to estimate average population $24 \mathrm{~h}$ sodium excretion? Results from the Isfahan Salt Study. Public Health Nutr. 2020;23:202-13.

26. Institute of Medicine, Dietary Reference Intakes for Water, Potassium, Sodium, Chloride, and Sulfate. 2005, Washington, DC: The National Academies Press.

27. Cotter J, Cotter MJ, Oliveira P, Cunha P, Torres E, Polonia J. Comparison of salt intake in children to that of their parents. Nephron. 2019;142:284-90.

28. Ohta Y, Iwayama K, Suzuki H, Sakata S, Hayashi S, Iwashima Y, et al. Salt intake and eating habits of school-aged children. Hypertens Res. 2016;39:812-7

29. Kelishadi R, Gheisari A, Zare N, Farajian S, Shariatinejad K. Salt intake and the association with blood pressure in young Iranian children: first report from the middle East and north Africa. Int J Prev Med. 2013;4:475-83.

30. Mirzaei M, Soltani M, Namayandeh M, GharahiGhehi N. Sodium and potassium intake of urban dwellers: nothing changed in Yazd. Iran J Health Popul Nutr. 2014;32:111-7.

31. Mohammadifard N, Khosravi A, Salas-Salvadó J, Becerra-Tomás N, Nouri F, Abdollahi Z, et al. Trend of salt intake measured by 24-hour urine collection samples among Iranian adults population between 1998 and 2013: The Isfahan salt study. Nutr Metab Cardiovasc Dis. 2019:29:1323-9.

32. Arsang-Jang S, Mansourian M, Mohammadifard N, Khosravi A, OveisGharan S, Nouri F, et al. Temporal trend analysis of stroke and salt intake: a 15-year population-based study. Nutr Neurosci. 2019;3:1-11.

33. Nazeri P, Mirmiran P, Mehrabi Y, Hedayati M, Delshad H, Azizi F. Evaluation of iodine nutritional status in Tehran, Iran: iodine deficiency within iodine sufficiency. Thyroid. 2010;20:1399-406.

34. Rafieifar S, Pouraram H, Djazayery A, Siassi F, Abdollahi Z, Dorosty AR, et al Strategies and opportunities ahead to reduce salt intake. Arch Iran Med. 2016;19:729-34.

35. Fahimi S, Pharoah P. Reducing salt intake in Iran: priorities and challenges. Arch Iran Med. 2012;15:110-2.

36. Rios-Leyvraz M, Bovet P, Bochud M, Genin B, Russo M, Rossier MF, et al. Estimation of salt intake and excretion in children in one region of Switzerland: a cross-sectional study. Eur J Nutr. 2019;58:2921-8.

37. Seko C, Taguchi Y, Segawa H, Odani K, Aoi W, Wada S, et al. Estimation of salt intake and sodium-to-potassium ratios assessed by urinary excretion among Japanese elementary school children. Clin Exp Hypertens. 2018:40:481-6. 
38. Correia-Costa L, Cosme D, Nogueira-Silva L, Morato M, Sousa T, Moura C, et al. Gender and obesity modify the impact of salt intake on blood pressure in children. Pediatr Nephrol. 2016;31:279-88.

39. Marrero NM, He FJ, Whincup P, MacGregor GA. Salt intake of children and adolescents in South London: consumption levels and dietary sources. Hypertension. 2014;63:1026-32.

40. Campanozzi A, Avallone S, Barbato A, lacone R, Russo O, De Filippo G, et al. High sodium and low potassium intake among Italian children: relationship with age, body mass and blood pressure. PLOS ONE. 2015;10:e0121183.

41. Zhang JY, Yan LX, Tang JL, Ma JX, Guo XL, Zhao WH, et al. Estimating daily salt intake based on $24 \mathrm{~h}$ urinary sodium excretion in adults aged 18-69 years in Shandong. China BMJ Open. 2014;4:e005089.

42. Han W, Wang W, Sun N, Li M, Chen L, Jiang S, et al. Relationship between 24-hour urinary sodium excretion and blood pressure in the adult population in Shandong. China J Clin Hypertens. 2019;21:1370-6.

43. Haghighatdoost F, Sarrafzadegan N, Khosravi A, Noori F, Boshtam M, Mohammadifard N, et al. Is the association between salt intake and blood pressure mediated by body mass index and central adiposity? Arch Iran Med. 2013:16:167-71.

44. Grillo A, Salvi L, Coruzzi P, Salvi P, Parati G. Sodium intake and hypertension. Nutrients. 2019;11:1970.

45. Naser AM, Rahman M, Unicomb L, Doza S, Anand S, Chang HH, et al. Comparison of urinary sodium and blood pressure relationship from the spot versus 24-hour urine samples. J Am Heart Assoc. 2019;8:e013287.

46. Johnson C, Mohan S, Rogers K, Shivashankar R, Thout SR, Gupta P, et al. Mean dietary salt intake in urban and rural areas in India: a population survey of 1395 persons. J Am Heart Assoc. 2017;6:e004547.

47. Hojhabrimanesh A, Akhlaghi M, Rahmani E, Amanat S, Atefi M, Najafi M, et al. A Western dietary pattern is associated with higher blood pressure in Iranian adolescents. Eur J Nutr. 2017:56:399-408.

48. Khosravi A, Kelishadi R, Sarrafzadegan N, Boshtam M, Nouri F, Zarfeshani $\mathrm{S}$, et al. Impact of a community-based lifestyle intervention program on blood pressure and salt intake of normotensive adult population in a developing country. J Res Med Sci. 2012;17:235-41.

49. Cashman KD, Kenny S, Kerry JP, Leenhardt F, Arendt EK. "Low-salt" bread as an important component of a pragmatic reduced-salt diet for lowering blood pressure in adults with elevated blood pressure. Nutrients. 2019;11:1725.
50. Farapti F, Sulistyowati M, Artanti KD, Setyaningtyas SW, Sumarmi S, Mulyana B. Highlighting of urinary sodium and potassium among indonesian schoolchildren aged 9-12 years: the contribution of school food. J Nutr Metab. 2019;3:2019.

51. Tan M, He FJ, Wang C, MacGregor GA. Twenty-four-hour urinary sodium and potassium excretion in china: a systematic review and meta-analysis. J Am Heart Assoc. 2019;8:e012923.

52. McGill CR, Fulgoni VL III, DiRienzo D, Huth PJ, Kurilich AC, Miller GD. Contribution of dairy products to dietary potassium intake in the United States population. J Am Coll Nutr. 2008;27:44-50.

53. Jennings A, Davies GJ, Costarelli V, Dettmar PW. Micronutrient intakes of pre-adolescent children living in London. Int J Food Sci Nutr. 2010;61:68-77.

54. Meneton P, Lafay L, Tard A, Dufour A, Ireland J, Menard J, et al. Dietary sources and correlates of sodium and potassium intakes in the French general population. Eur J Clin Nutr. 2009;63:1169-75.

55. Stein LJ, Cowart BJ, Beauchamp GK. The development of salty taste acceptance is related to dietary experience in human infants: a prospective study. Am J Clin Nutr. 2012;95:123-9.

56. Moliterno P, Álvarez-Vaz R, Pécora M, Luzardo L, Borgarello L, Olascoaga $A$, et al. Blood pressure in relation to 24-hour urinary sodium and potassium excretion in a uruguayan population sample. Int J Hypertens. 2018;1:2018.

57. Jackson SL, Cogswell ME, Zhao L, Terry AL, Wang CY, Wright J, et al. Association between urinary sodium and potassium excretion and blood pressure among adults in the United States: national health and nutrition examination survey, 2014. Circulation. 2018;137:237-46.

58. Mente A, O'Donnell MJ, Rangarajan S, McQueen MJ, Poirier P, Wielgosz A, et al. Association of urinary sodium and potassium excretion with blood pressure. N Engl J Med. 2014;371:601-11.

59. Nguyen TT, Miura K, Tanaka-Mizuno S, Tanaka T, Nakamura Y, Fujiyoshi A, et al. Association of blood pressure with estimates of 24-h urinary sodium and potassium excretion from repeated single-spot urine samples. Hypertens Res. 2019;42:411-8.

\section{Publisher's Note}

Springer Nature remains neutral with regard to jurisdictional claims in published maps and institutional affiliations.
Ready to submit your research? Choose BMC and benefit from:

- fast, convenient online submission

- thorough peer review by experienced researchers in your field

- rapid publication on acceptance

- support for research data, including large and complex data types

- gold Open Access which fosters wider collaboration and increased citations

- maximum visibility for your research: over $100 \mathrm{M}$ website views per year

At BMC, research is always in progress.

Learn more biomedcentral.com/submissions 